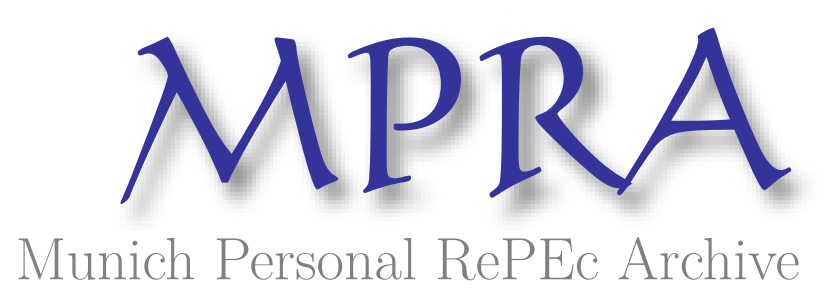

\title{
Trade Complementarity and Similarity Between India and Asean Countries in the context of the RTA
}

Sarath Chandran, B.P.

VVM's Shree Damodar College of Commerce and Economics, Goa

7 August 2010

Online at https://mpra.ub.uni-muenchen.de/29279/

MPRA Paper No. 29279, posted 09 Mar 2011 07:54 UTC 


\title{
TRADE COMPLEMENTARITY AND SIMILARITY BETWEEN INDIA AND ASEAN COUNTRIES IN THE CONTEXT OF THE RTA
}

\author{
B.P. Sarath Chandran \\ Assistant Professor in Economics \\ VVM's Shree Damodar College of Commerce and Economics, \\ Margao, Goa.
}

\section{Introduction}

As the regionalization efforts of international trade gets intensified due to limited progress at the multilateral trade negotiations, India is making serious regional engagements to consolidate its trade positions. After initiating bilateral trade agreements with Sri Lanka, Singapore, Thailand and South Korea, for the first time it signed a RTA with a regional block, ASEAN on $13^{\text {th }}$ August 2009. India ASEAN Free Trade Agreement (IAFTA) generated intense discussion on the economic impact on India's trade in goods particularly on certain agricultural sectors where the livelihood of large number of people were depended upon. For any Regional Trade Agreement (RTA) to be successful, it is imperative on partner countries to have complementary trade structure to be exploited for mutual benefit. Countries which got complementary trade structure are likely to trade more where as economies with similar trade structure often struggle to improve trade share unless there is substantial intra industry trade. RCA indices, despite their limitations, provide a useful guide to underlying comparative advantage and offer a further insight into the competitiveness of participating countries and hence reveal the possibility of increased trade cooperation between them. In this context the paper tried to identify complementary and competing sectors of trade between India and ASEAN countries to consolidate their strengths and to overcome the pitfalls. The synergies between India and ASEAN need to be identified for further cementing the economic cooperation and deepening the relationship. 


\section{Methodology}

The study used Trade Intensity Index (TII) and Revealed Comparative Advantage (RCA) Index to see trade complementarity and Similarity between India and ASEAN countries. The trade intensity index (TII) is used to determine whether the value of trade between two countries is greater or smaller than would be expected on the basis of their importance in world trade. It is defined as the share of one country's exports going to a partner divided by the share of world exports going to the partner. It is calculated as,

$T_{i j}=\frac{\left(x_{i j} / X_{i t}\right)}{\left(x_{w j} / X_{w t}\right)}$

Where $\mathrm{x}_{\mathrm{ij}}$ and $\mathrm{x}_{\mathrm{wj}}$ are the values of country $\mathrm{i}$ 's exports and of world exports to country $\mathrm{j}$ and where $X_{\mathrm{it}}$ and $\mathrm{X}_{\mathrm{wt}}$ are country i's total exports and total world exports respectively. An index of more (less) than one indicates a bilateral trade flow that is larger (smaller) than expected, given the partner country's importance in world trade.

Trade Intensity Index is further divided in to Export Intensity Index (EII) and Import Intensity Index (III) for looking the pattern of exports and Imports. Following Kojima (1964) and Drysdale (1969), the index of trade intensity is restated as follows,

EII between India and ASEAN $=\frac{\boldsymbol{X}_{I A} / \boldsymbol{X}_{I}}{\boldsymbol{M}_{A} /\left(\boldsymbol{M}_{W}-M_{I}\right)}$

$\mathrm{X}_{\mathrm{IA}}=$ India's Export to ASEAN; $\mathrm{X}_{\mathrm{I}}=$ India's total Export; $\mathrm{M}_{\mathrm{A}}=$ Total Import of ASEAN;

$\mathrm{M}_{\mathrm{w}}=$ Total World imports $\mathrm{M}_{\mathrm{I}}=$ Total Imports of India

III between India and ASEAN $=\frac{\boldsymbol{M}_{I A} / \boldsymbol{M}_{I}}{\boldsymbol{X}_{\boldsymbol{A}} /\left(\boldsymbol{X}_{W}-\boldsymbol{X}_{I}\right)}$ 
$\mathrm{M}_{\mathrm{IA}}=$ Import of India from ASEAN; $\mathrm{M}_{\mathrm{I}}=$ Total Import of India; $\mathrm{X}_{\mathrm{A}}=$ Total Export of ASEAN; $X_{W}=$ Total World Export; $X_{I}=$ Total Export of India

Trade Intensity Index is calculated for India and ASEAN countries for the period 1990 to 2007 taking data from UN COMTRADE and accessed through World Integrated Trade Solutions (WITS).

Revealed Comparative Advantage Index shows how competitive is a product in countries' export compared to the products share in world trade. A product with high RCA is competitive and can be exported to countries with low RCA. Countries with similar RCA profiles are unlikely to have high bilateral trade intensities unless intra industry trade is involved. RCA measures, if estimated at high levels of product disaggregation, can focus attention on other nontraditional products that might be successfully exported. The RCA index of country ' $\mathrm{i}$ ' for product ' $\mathrm{j}$ ' is often measured by the product's share in the country's exports in relation to its share in world trade:

$R C A_{i j}=\frac{\left(x_{i j} / X_{i t}\right)}{\left(x_{w j} / X_{w t}\right)}$

Where $x_{i j}$ and $x_{w j}$ are the values of country i's exports of product $\mathrm{j}$ and world exports of product $\mathrm{j}$ and where $X_{\mathrm{it}}$ and $\mathrm{X}_{\mathrm{wt}}$ refer to the country's total exports and world total exports. A value of less than unity implies that the country has a revealed comparative disadvantage in the product. Similarly, if the index exceeds unity, the country is said to have a revealed comparative advantage in the product.

In the present study RCA is calculated for eight ASEAN countries across 16 major commodity groups for 17 years to identify specific advantage in trade. The commodities for which RCA are calculated include Agricultural Products, Food, Fuels and Mining, Fuels, Manufactures, Iron and Steel, Machinery and Transport Equipment, Office and 
Telecom equipments, EDP and OE, IC and EC, Pharmaceuticals, Chemicals, Automotive, Textiles and Clothing. Data for calculating RCA are collected from IMF, WTO and ASEAN Statistical Yearbook.

\section{Trade Intensity Index between ASEAN and India}

It is revealed from Table 1 that India's export intensity as well as import intensity with ASEAN is above one for most of the years. This means India's exports and imports are intense with ASEAN countries compared with its trading pattern with rest of the world. The natural trading partner theory reveals countries tend to trade more with neighbors and close proximate partners. ASEAN countries being geographically closer to India, value of these indices are likely to come down once it is adjusted for geographical distance. ASEAN's Export Intensity Index is higher than Import Intensity Index as it exports more to India compared to its imports.

Table: 1 Trade Intensity Index between ASEAN and India

\begin{tabular}{|l|l|l|l|l|}
\hline Year & $\begin{array}{l}\text { India's EII with } \\
\text { ASEAN }\end{array}$ & $\begin{array}{l}\text { ASEAN's EII } \\
\text { with India }\end{array}$ & $\begin{array}{l}\text { India's III with } \\
\text { ASEAN }\end{array}$ & $\begin{array}{l}\text { ASEAN's III } \\
\text { with India }\end{array}$ \\
\hline 1990 & 0.9127 & 1.7143 & 1.5770 & 1.5372 \\
\hline 1995 & 1.0903 & 1.5260 & 1.1218 & 1.2206 \\
\hline 2000 & 1.1437 & 1.9671 & 1.2942 & 1.2737 \\
\hline 2005 & 1.8592 & 1.7215 & 1.1954 & 1.4685 \\
\hline 2006 & 1.4429 & 1.5353 & 1.6801 & 1.3635 \\
\hline 2007 & 1.4872 & 1.4775 & 1.6059 & 1.3997 \\
\hline
\end{tabular}

Source: Computed from UN COMTRADE Statistics

Country wise look at the trade intensity showed India's export Intensity is above one for Indonesia, Malaysia, Myanmar, Singapore, Thailand and Vietnam. For others (Brunei, Laos, Cambodia and Philippines) the export intensity is fluctuating over the years. Myanmar, Singapore and Vietnam are the three countries with whom India got high 
export intensity. For the year 2007, except Cambodia, Laos and Philippines, India got high trade intensity with all ASEAN countries. Tables 2 gave the country wise export and import intensity of India with ASEAN countries.

India is importing smaller volumes from the less developed countries of ASEAN which is reflected in the low Import intensity Index with Brunei, Cambodia and Lao PDR. Imports are also restricted with Philippines and Vietnam with import intensity well below one.

Table: 2 India's Export and Import Intensity Index with ASEAN Countries

\begin{tabular}{|l|l|l|l|l|l|l|l|l|l|l|l|}
\hline Year & & BRU & CAM & INDO & LAO & MAL & MYA & PHI & SING & THAI & VIET \\
\hline \multirow{2}{*}{1990} & EII & 0.05 & 4.58 & 0.82 & 0.10 & 0.84 & 0.42 & 0.32 & 0.99 & 1.18 & 0.57 \\
\cline { 2 - 12 } & III & 0.00 & 0.00 & 0.94 & 0.82 & 2.60 & 30.93 & 0.07 & 1.83 & 0.38 & 3.30 \\
\hline \multirow{2}{*}{1995} & EII & 0.28 & 0.20 & 2.06 & 0.09 & 0.77 & 1.52 & 0.72 & 1.08 & 1.00 & 1.95 \\
\cline { 2 - 12 } & III & 0.00 & 11.84 & 1.24 & 0.00 & 1.53 & 19.62 & 0.12 & 1.20 & 0.36 & 0.40 \\
\hline \multirow{2}{*}{2000} & EII & 0.30 & 0.85 & 1.77 & 1.11 & 1.06 & 2.43 & 0.84 & 0.94 & 1.26 & 2.04 \\
\cline { 2 - 12 } & III & 0.01 & 0.12 & 1.87 & 0.00 & 1.78 & 11.40 & 0.20 & 1.35 & 0.61 & 0.11 \\
\hline \multirow{2}{*}{2005} & EII & 2.17 & 0.95 & 2.56 & 0.40 & 1.08 & 3.37 & 1.08 & 2.80 & 0.94 & 1.93 \\
\cline { 2 - 12 } & III & 0.01 & 0.02 & 2.54 & 0.01 & 1.28 & 10.17 & 0.37 & 1.03 & 0.77 & 0.28 \\
\hline \multirow{2}{*}{2006} & EII & 2.05 & 0.83 & 1.80 & 0.35 & 0.92 & 3.58 & 0.70 & 1.84 & 1.13 & 1.74 \\
\cline { 2 - 11 } & III & 0.01 & 0.01 & 2.01 & 0.01 & 2.23 & 8.86 & 0.18 & 1.97 & 0.98 & 0.24 \\
\hline \multirow{2}{*}{2007} & EII & 1.21 & 0.53 & 1.77 & 0.32 & 1.19 & 3.07 & 0.59 & 1.90 & 1.25 & 1.49 \\
\cline { 2 - 10 } & III & 0.01 & 0.01 & 1.85 & 0.01 & 2.03 & 8.75 & 0.13 & 2.03 & 1.06 & 0.22 \\
\hline
\end{tabular}

Source: Computed from UN COMTRADE Statistics

India's import intensity was small with Thailand for many years but improved strongly after signing the bilateral trade agreement. India's imports from ASEAN traditionally confined to Singapore and Malaysia. Import intensity is markedly high with Myanmar as it shares geographical border with India and in close proximate with north eastern states of India. This exceptionally high import intensity is also due to Myanmar's low imports from the rest of the world due to political reasons. For all other countries, the index follows a range except for Cambodia in the year 1995. 


\title{
4. Analysis of Revealed Comparative Advantage (RCA) between India and
}

\begin{abstract}
ASEAN
The table-3 gives the mean Revealed Comparative Advantage (RCA) of ASEAN countries and India for the period 1990 and 2006 for 16 product categories. The mean RCA for agricultural commodity is above one for India, Indonesia, Malaysia, Philippines, Thailand and Vietnam and below one for Brunei, Cambodia and Singapore. This means there is a scope to trade agricultural Commodities between India and low RCA countries of ASEAN such as Brunei, Cambodia and Singapore. Food items form part of agricultural products and resemble the same pattern of RCA that of agricultural products. RCA for food is high for India, Indonesia, Malaysia, Thailand and Vietnam and low for Brunei, Cambodia, Philippines and Singapore. The average RCA showed that the two ASEAN countries namely Vietnam and Thailand are having a strong RCA of above two. But Brunei, Cambodia and Singapore got a very low RCA in food and India which got a mean RCA of 1.8374 can export food articles to these nations.
\end{abstract}

Fuel and Mining are resource based products depending on the natural endowments of the country. But industries can be established to process and refine these products. For Mining and Fuels, RCA is high in Brunei, India, Indonesia, and Vietnam and low in Cambodia, Malaysia, Singapore and Thailand. The mean RCA shows, Brunei and Indonesia and Vietnam got Revealed Comparative Advantage for fuel and mining products and they can export fuel products to Cambodia, Philippines, Thailand, Malaysia, Singapore and India who have Revealed Comparative Disadvantage. This showed there is complementarity in trading fuel products in the ASEAN region. With regard to the mining products alone, India got the comparative advantage in many product categories and can export them to most of the ASEAN countries. 
Table: 3 Mean RCA for India and ASEAN in Major Commodity Groups

\begin{tabular}{|l|l|l|l|l|l|l|l|l|l|}
\hline $\begin{array}{l}\text { Commodity } \\
\text { Categories }\end{array}$ & INDIA & BRU & CAM & INDO & MALA & PHI & SING & THA & VIET \\
\hline Agriculture & $\mathbf{1 . 6 2}$ & 0.01 & 0.34 & $\mathbf{1 . 5 7}$ & $\mathbf{1 . 3 4}$ & $\mathbf{1 . 0 1}$ & 0.40 & $\mathbf{2 . 0 9}$ & $\mathbf{3 . 0 1}$ \\
\hline Food & $\mathbf{1 . 8 4}$ & 0.02 & 0.13 & $\mathbf{1 . 3 8}$ & $\mathbf{1 . 0 7}$ & $\mathbf{1 . 1 8}$ & 0.40 & $\mathbf{2 . 2 5}$ & $\mathbf{3 . 4 7}$ \\
\hline Fuel \& Mining & 0.66 & $\mathbf{7 . 3 3}$ & 0.01 & $\mathbf{2 . 6 3}$ & 0.91 & 0.40 & 0.95 & 0.25 & $\mathbf{1 . 7 7}$ \\
\hline Fuels & 0.41 & $\mathbf{7 . 7 6}$ & 0.00 & $\mathbf{2 . 9 6}$ & $\mathbf{1 . 0 9}$ & 0.17 & $\mathbf{1 . 1 3}$ & 0.23 & $\mathbf{2 . 2 7}$ \\
\hline Manufacture & $\mathbf{1 . 0 6}$ & 0.09 & $\mathbf{1 . 3 5}$ & 0.66 & $\mathbf{1 . 0 2}$ & $\mathbf{1 . 1 6}$ & $\mathbf{1 . 1 9}$ & $\mathbf{1 . 0 1}$ & 0.66 \\
\hline Iron \& Steel & $\mathbf{1 . 2 8}$ & 0.06 & 0.001 & 0.34 & 0.34 & 0.10 & 0.26 & 0.37 & 0.12 \\
\hline Chemicals & $\mathbf{1 . 0 4}$ & 0.01 & 0.01 & 0.41 & 0.37 & 0.19 & 0.84 & 0.50 & 0.13 \\
\hline Pharmaceutical & $\mathbf{1 . 3 2}$ & 0.01 & 0.07 & 0.04 & 0.03 & 0.41 & 0.07 & 0.02 & \\
\hline $\begin{array}{l}\text { Machinery \& } \\
\text { Transp. Equp }\end{array}$ & 0.23 & 0.10 & 0.02 & 0.27 & $\mathbf{1 . 4 0}$ & $\mathbf{1 . 5 7}$ & $\mathbf{1 . 7 0}$ & 0.98 & 0.21 \\
\hline $\begin{array}{l}\text { Office \& Tel } \\
\text { Equipments }\end{array}$ & 0.09 & 0.03 & 0.004 & 0.48 & $\mathbf{3 . 6 4}$ & $\mathbf{4 . 1 7}$ & $\mathbf{4 . 3 3}$ & $\mathbf{1 . 8 7}$ & 0.30 \\
\hline $\begin{array}{l}\text { EDP \& Office } \\
\text { Equipments }\end{array}$ & 0.12 & 0.01 & 0.01 & 0.70 & $\mathbf{3 . 6 3}$ & $\mathbf{3 . 9 5}$ & $\mathbf{3 . 5 3}$ & $\mathbf{2 . 2 1}$ & 0.49 \\
\hline $\begin{array}{l}\text { Tel. } \\
\text { Equipments }\end{array}$ & 0.12 & 0.04 & 0.01 & $\mathbf{1 . 0 5}$ & $\mathbf{2 . 5 3}$ & 0.65 & $\mathbf{1 . 5 0}$ & $\mathbf{1 . 2 6}$ & 0.20 \\
\hline $\begin{array}{l}\text { IC \& EC } \\
\text { Products }\end{array}$ & 0.07 & 0.00 & 0.00 & 0.29 & $\mathbf{5 . 0 0}$ & $\mathbf{1 0 . 6 4}$ & $\mathbf{6 . 4 3}$ & $\mathbf{1 . 7 1}$ & 0.14 \\
\hline Automotive & 0.20 & 0.02 & 0.02 & 0.07 & 0.05 & 0.19 & 0.08 & 0.33 & 0.01 \\
\hline Textiles & $\mathbf{4 . 8 8}$ & 0.12 & 0.48 & $\mathbf{2 . 0 3}$ & 0.49 & 0.41 & 0.37 & $\mathbf{1 . 2 2}$ & 0.92 \\
\hline Clothing & $\mathbf{4 . 0 7}$ & 0.86 & $\mathbf{2 4 . 4 6}$ & $\mathbf{2 . 2 3}$ & 0.93 & $\mathbf{3 . 5 2}$ & 0.48 & $\mathbf{2 . 2 9}$ & $\mathbf{4 . 8 1}$ \\
\hline
\end{tabular}

Source: Computed from WTO database

Manufactured commodities are value added products and exports of these products depend on the industrial development of the country. The computation of RCA for manufacture products showed India, Cambodia, Malaysia, Philippines, Singapore and Thailand had RCA above one where as Brunei, Indonesia and Vietnam got RCA below one. But the disaggregation of Manufacture products in to different categories showed that countries enjoy clear RCA in specific product categories. In the case of Iron and Steel industry, all the ASEAN countries got comparative disadvantage where as India enjoy a high RCA in the product. This industry depends on the availability of natural resource in a country and India got huge iron ore reserve in the country. India can export iron and steel to most of the ASEAN countries. 
The computation of RCA for Chemicals showed that India developed comparative advantage in the product category over the period of time. Currently India is exporting different chemical products and increasing the export share in its export basket. India got Revealed Comparative Advantage in Chemicals where as all the other ASEAN countries have revealed comparative disadvantage pointing out India can improve trade in Chemical products with the ASEAN countries. India's comparative advantage in this knowledge based industry is the reflection of the capacity developed over the period of time. All the ASEAN countries have Comparative Disadvantage in this category even though Philippines is slowly increasing its share over time. There is a prospect higher trade between India and ASEAN countries in Pharmaceutical Products.

Singapore, Malaysia, Philippines and recently Thailand have been exporting more Machinery and Transport Equipment and showing Comparative Advantage in this product category. The disadvantaged countries in the product group include India, Brunei, Cambodia, Indonesia and Vietnam. This reveals there is scope for trading Machinery and Transport Equipment within ASEAN countries and ASEAN and India. In this high technology industry; Singapore, Malaysia, Philippines and Thailand developed competencies and exporting large share of products to other countries. The mean RCA is above two for Singapore, Philippines and Malaysia where it is above one for Thailand. On the other hand countries like India, Brunei, Cambodia, Indonesia and Vietnam have to go a long way in developing comparative advantage and exporting these products to other countries. This gives scope for higher intra regional trade for Office and Telecom Equipment and between Singapore, Malaysia, Thailand and India. If we take the Electronic Data Processing and Office Equipment separately it follows the same pattern. Singapore, Malaysia, Philippines and Thailand had higher mean RCA and rest of ASEAN and India got comparative disadvantage. 
Malaysia enjoys high export performance of Telecom Equipment and there by possessing significant comparative advantage followed by Singapore and Thailand in the region. Indonesia whose RCA was above one during early 2000, slipped its position after 2005 when RCA fell below one. The less developed countries of ASEAN, Philippines and India got comparative disadvantage in this product category giving scope for higher trade among these countries. Integrated Circuits and Electronic Components are an important input for the development of electronics and communication industry which is growing at a rapid rate in this information age. East Asian Countries like Singapore, Malaysia, Philippines and Thailand developed competencies in this sector and have a strong RCA. The high mean RCA of Philippines (10.64), Singapore (6.43), Malaysia (5.00) and Thailand (1.71) shows the strong export performance of this high value technology sector. On the other hand the remaining East Asian countries like Brunei, Cambodia, Indonesia, Vietnam and India got Revealed Comparative Disadvantage in this category. This showed that large potential for bilateral trade for this important input component and increased trade among ASEAN countries and between India and ASEAN.

Automotive is an important component in the manufacturing sector with strong backward linkage and employment potential. But ASEAN countries as well as India do not have comparative advantage in this sector. This is because of the dominance and Japanese companies for long and Korea recently. India has been attracting foreign entry and investment in this sector and exporting cars manufactured by Multinational (Maruthi Suzuki, Hyundai) particularly to European nations but yet to develop RCA for sizable export share and market dominance.

Textiles is labour intensive sector with high employment potential and most of the developing countries of Asia depend on their export to earn their foreign exchange. India traditionally exported large quantity of Textile products and revealed significant 
Comparative Advantage. Indonesia and Thailand also possess considerable export performance and RCA as their export shares are above the world share. The mean RCA computed in the study is 4.88 for India, 2.03 for Indonesia and 1.22 for Thailand. Most of the ASEAN countries have low RCA showing the complementarity existing in the sector and they can trade more with India for their requirement. But the dismantling of MFA (Multi Fibre Agreement) bring in strong players like China dominating the market and India need to equip itself to take care of this advantage. There is increased competition in the clothing sector in the East Asian region as most of the developing countries having strong comparative advantage along with India. The mean RCA for Cambodia (24.46), Vietnam (4.81), Philippines (3.52), Thailand (2.29), and Indonesia (2.23) are high and these countries are major exporters of clothing to the rest of the world. India is also a major exporter of clothing to the world and there is limited complementarity between India and ASEAN countries for increased trade in this sector.

\section{Conclusion}

Inferences from the trade indices computed for understanding the trade structure between India and ASEAN revealed that there are complemetary sectors and products available for enhancing trade cooperation between the trading partners. ASEAN countries are in different stages of economic development and India can have trade cooperation with some of them in all product categories. While India can export food grains to small and developed countries of ASEAN, it can import edible and other agricultural products from other ASEAN countries. India enjoys advantage in minerals whereas they can import crude oil from ASEAN. India had advantage in some manufactured items like chemicals, Iron and Steel, Jems and Jewellery and can export them to many ASEAN countries. ASEAN has comparative advantage in Electrical and Electronic components and India 
can import them from ASEAN. With regard to Textiles and Clothing there is intense competition between ASEAN and India to increase market share. India's average tariff is higher than ASEAN countries and reduction of tariffs will have a short term impact on India's exports but can consolidate in the medium term through productivity gains and efficiency. Also emerging economic structure warrants greater cooperation from India in the regionalization efforts in Asia.

\section{References}

Balassa, Bela. 1965. "Trade Liberalization and Revealed Comparative Advantage". The Manchester School of Economic and Social Studies, No. 33: 99-123.

Balassa, Bela. 1977. “'Revealed' Comparative Advantage Revisited: An Analysis of Relative Export Shares of the Industrial Countries, 1953-1971”. The Manchester School of Economic \& Social Studies, 45(4): 327-44

Baldwin, Richard. 1993. “A domino theory of regionalism'. CEPR Discussion Paper 857; NBER Working Paper, 4465.

Baldwin, R.E. 1997. “The Causes of Regionalism”. The World Economy, 20(7): 865-888. Batra, Amita and Zeba Khan. 2005. "Revealed Comparative Advantage: An Analysis for India and China”. Indian Council for Research on International Economic Relations (ICRIER), Working Paper No. 168, New Delhi.

Burange, L.G; and Sheetal, J. Chaddha. 2008. “India's Revealed Comparative Advantage in Merchandise Trade". Department of Economics, University of Mumbai, Working Paper UDE 28/06/2008.

Chow, Peter C. Y. 1990. "The Revealed Comparative Advantage of the East Asian NICs". The International Trade Journal, 5(2): 235 - 262. 
Ferto, Imre and Lionel J. Hubbard. 2002. "Revealed Comparative Advantage and Competitiveness in Hungarian Agri-Food Sectors". Institute of Economics, Hungary Academy of Sciences, Budapest, Discussion Paper Series 2002/8.

Kawai, Masahiro (2004), 'Regional Economic Integration and Cooperation in East Asia,' mimeo

Kumar, N. 2002. "Towards an Asian Economic Community: The Relevance of India". Research and Information System for Non-Aligned and other Developing Countries (RIS), Discussion Paper No.34, New Delhi.

Lipsey. 1960. “The theory of customs unions: A general survey”. Economic Journal, 70 September: 496-513.

Meade, J.E. 1955. “The Theory of Customs Unions”. Amsterdam: North-Holland.

Panagaria, Arvind. 2000. "Preferential Trade Liberalization: The Traditional Theory and New Developments”. Journalof Economic Literature. XXXVIII: 287-331.

Soloaga, Isidro, and L. Alan Winters. 1999. "How Has Regionalism in the 1990s Affected Trade?". Policy Research Working Paper Series no. 2156. World Bank, Washington, D.C.

Viner, J. 1950. "The customs union issue". New York: Carnegie Endowment for International Peace.

World Trade Organisation (WTO). 2008. "International Trade Statistics”, Geneva.

World Bank. 2005, "Trade, Regionalism and Development". Global Economic Prospects, Washington, D. C: World Bank. 